\title{
Comparative effects of fructose and glucose on the lipid and carbohydrate metabolism of perfused rat liver
}

\author{
By D. L. TOPPING AND P. A. MAYES \\ Division of Biochemistry, Department of Physiology, \\ Royal Veterinary College, London $N W_{\mathrm{I}}$ oTU \\ (Received 25 November 1975 - Accepted 29 Fanuary 1976)
}

\begin{abstract}
1. Livers from rats fed on a standard diet were perfused with whole blood, and infused continuously with glucose and fructose at equimolar rates.

2. Infusion of fructose increased both the secretion of very-low-density-lipoprotein (VLDL)-triglycerides and the incorporation of free fatty acids (FFA) from the perfusate into VLDL-lipids, but neither of these two processes was affected by infusion of glucose.

3. Infusion of fructose decreased the oxidation and increased the esterification of FFA, but glucose infusion had no effect on these processes. When fructose and glucose were infused together there was a further decrease in oxidation.

4. When fructose was infused alone or together with glucose, blood concentrations rapidly became stabilized at those found in the hepatic portal vein in vivo, with similar rates of hepatic uptake to those found in the intact animal. Infusion of glucose alone resulted in continuously increasing perfusate glucose concentrations, and rates of uptake which were only $20 \%$ of those for fructose. Blood glucose concentrations were reduced, and lactate concentrations were increased by fructose infusion, and when glucose and fructose were infused together there was a greatly increased rate of glucose uptake.

5. Liver glycogen was not affected by the infusion of fructose or glucose alone; however, their combined addition significantly increased its concentration.

6. Uptake of perfusate FFA was not affected by either fructose or glucose infusions.

7. The results are discussed in terms of the differences in nutrition and metabolism between glucose and fructose, with particular reference to the development of hypertriglyceridaemia.
\end{abstract}

The feeding of diets high in simple carbohydrates increases the concentrations of plasma triglycerides in both experimental animals and man. This increase is obtained when the principal dietary carbohydrate is fructose or sucrose, but not glucose, maltose or starch (Macdonald, I965). The liver is the main source of serum triglycerides present in the very-low-density lipoproteins (VLDL), and these are derived by either long-chain fatty acid synthesis (Windmueller \& Spaeth, 1967; Mayes \& Topping, I974) or the esterification of plasma free fatty acids (FFA) (Stein \& Shapiro, I959; Havel, Felts \& Van Duyne, I962; Mayes \& Felts, I967).

In an earlier study on the perfused rat liver (Topping \& Mayes, 1972) it was found that fructose, at concentrations found in the hepatic portal venous blood of rats absorbing fructose (Topping \& Mayes, 1971), reduced the oxidation of FFA taken up from the perfusate, and stimulated their esterification and the release of VLDLtriglycerides. However, during the digestion and absorption of dietary sucrose both fructose and glucose enter the hepatic circulation from the intestine; therefore, to simulate this situation in vitro the perfused liver should be infused with both monosaccharides.

The results of most studies reported would suggest that the hypertriglyceridaemic 
effect of feeding sucrose is due mainly to the unique metabolic effects of the fructose moiety of the molecule. However, Naismith (1971) presented evidence which suggested that the effect was due to the recurrent flooding of the liver cells with high concentrations of monosaccharides, and that any difference between the metabolism of fructose and glucose is comparatively unimportant as a factor determining the hyperlipidaemic effect of sucrose. It was decided to put these divergent views to the test by comparing the metabolic effects of fructose and glucose on the perfused liver when they were infused at equimolar rates, both alone and together. A preliminary account of some of this work has been presented (Topping \& Mayes, I973).

\section{MATERIALS AND METHODS}

\section{Liver perfusions}

Livers from male Wistar albino rats $(340-360 \mathrm{~g})$, fed on a standard pelleted diet, MRC no. 4I B (Bruce \& Parkes, 1949), were isolated and perfused for an experimental period of $90 \mathrm{~min}$, essentially as described by Mayes \& Felts (1966). The perfusate was $140 \mathrm{ml}$ defibrinated whole blood, withdrawn under light diethyl ether anaesthesia from male rats $(300-500 \mathrm{~g})$ of the same strain. To remove vasoconstrictor factors, the blood was dialysed for $24 \mathrm{~h}$ at $0-4^{\circ}$ using three consecutive volumes (1 1 each) of Krebs \& Henseleit (1932) bicarbonate buffer containing glucose (I 1 I $\mathrm{mmol} / \mathrm{l}$ ) and mixed amino acids $(500 \mathrm{mg} / \mathrm{l})$.

The rate of perfusion was $12 \mathrm{ml}$ blood $/ \mathrm{min}$ which was approximately $1.0 \mathrm{ml} / \mathrm{g}$ liver per min. Perfusion was achieved by pumping blood direct to the liver using a peristaltic pump (Watson-Marlow Ltd, Falmouth, Cornwall). To assist in the maintenance of liver temperature the organ was held in a water-jacket bowl, and the perfusate was passed through a heat-exchanger immediately before entering the liver. Thus the temperature of the organ was held within the range $37 \pm 0 \cdot 1^{\circ}$. The partial pressure of oxygen $\left(P_{\mathrm{O}_{2}}\right)$ in the blood was monitored continuously with an $\mathrm{O}_{2}$ electrode and maintained at $90-100 \mathrm{~mm} \mathrm{Hg}$.

\section{Substrate infusions}

When the liver was in equilibrium with respect to temperature, flow-rate and $P_{\mathrm{O}_{2}}$, substrate infusion was started (o min). In all experiments $5 \mu \mathrm{Ci}\left[\mathrm{r}-{ }^{14} \mathrm{C}\right]$ oleic acid (specific radioactivity $50 \mathrm{mCi} / \mathrm{mmol}$; Radiochemical Centre, Amersham, Bucks.) and $78 \mathrm{mg}$ unlabelled oleic acid (Sigma Ltd, Kingston-upon-Thames, Surrey) were complexed with I $g$ crystalline bovine serum albumin (Armour Pharmaceutical Co., Eastbourne, Sussex) as described previously (Topping \& Mayes, 1972). The complex was infused to maintain concentrations of $0.7-0.8 \mathrm{mmol} \mathrm{FFA} / 1$ serum. This was achieved by means of an initial rapid rate of infusion to establish the desired concentration, then a slower rate of infusion. Fructose (bacteriological grade; British Drug Houses, Poole, Dorset) was similarily infused as a $40 \mathrm{~g} / \mathrm{l}$ solution in saline ( $9 \mathrm{~g}$ sodium chloride/l). Glucose $(4 \circ \mathrm{g} / \mathrm{l}$ saline) was infused at the same rate as fructose. When fructose and glucose were infused together they were mixed in the same saline solution to give a $40 \mathrm{~g} / \mathrm{l}$ solution of each hexose. Control perfusions 
were infused with a saline solution only. The amount of total radioactivity infused was determined from a timed collection of the $\left[\mathrm{I}^{14} \mathrm{C}\right]$ oleic acid infusion.

\section{Sampling}

Samples (1 $10 \mathrm{ml}$ ) of the perfusate were taken at $0 \mathrm{~min}$ and at $30 \mathrm{~min}$ intervals, and immediately chilled in ice. Smaller samples $(0.5 \mathrm{ml})$ from the hepatic venous cannula were also taken. At the end of $90 \mathrm{~min}$ the liver was removed, gently blotted and a portion $\left(0.5^{-1} \cdot \mathrm{Og}\right)$ taken for glycogen determination, the remainder was weighed before homogenization in chloroform-methanol $(2: \mathrm{I}, \mathrm{v} / \mathrm{v})$.

In calculating perfusate volumes and the rates of production of metabolites, corrections were applied for the volumes of samples removed, bile produced, and substrates infused.

\section{Analytical techniques}

Perfusate fructose was determined by the Long (1957) modification of the Roe (1934) procedure. A correction was applied for any interference by glucose, which amounted to no more than the equivalent of $0.08 \mathrm{mmol}$ fructose/ 1 blood. Liver glycogen was isolated and hydrolysed (Good, Kramer \& Somogyi, 1933) and, after neutralization, the liberated glucose estimated using a glucose oxidase kit (Boehringer Corporation, Lewes, East Sussex). This method was also used to determine perfusate glucose. $\mathrm{L}(+)$-lactate was determined by the method of Hohorst (1965).

Serum samples ( $\mathrm{I} \mathrm{ml}$ ), obtained by centrifuging blood at $2500 \mathrm{rev} . / \mathrm{min}$ for $20 \mathrm{~min}$ at $4^{\circ}$, were placed in cellulose nitrate tubes and an upper layer of saline solution (density $\mathrm{I} \cdot 006 \times 10^{3} \mathrm{~kg} / \mathrm{m}^{3}$ ) was added. VLDL (density $<\mathrm{I} \cdot 006 \times 10^{3} \mathrm{~kg} / \mathrm{m}^{3}$ ) were separated by ultracentrifugation and their component lipids extracted with chloroformmethanol $(2: 1, v / v)$ as described previously (Topping \& Mayes, 1972). The chloroform-methanol extracts were partitioned with 0.4 vol. $0.03 \mathrm{M}-\mathrm{HCl}$, portions of the chloroform extracts were dried under nitrogen, and the component lipids were separated by thin-layer chromatography using silica gel G (E. Merck AG; obtained from Anderman \& Co., London) with hexane-diethyl ether-glacial acetic acid (70:30:2, by vol.) as the developing solvent. Lipids were visualized with iodine vapour, the appropriate areas of silica gel were transferred to vials when the iodine had evaporated, and the amount of radioactivity was measured by liquid-scintillation spectrometry (described later). Phospholipids were extracted from the silica gel with chloroformmethanol-ammonia $\left(5^{\circ}: 50: 10\right.$, by vol.) and portions of the extracts were transferred to vials, dried under air, and the amount of radioactivity measured. Extracts of lipoproteinlipids (density $>\mathrm{r} \cdot 006 \times 1 \mathrm{r}^{3} \mathrm{~kg} / \mathrm{m}^{3}$ ) (mainly ${ }^{14} \mathrm{C}$-labelled FFA) were separated on silica gel $\mathrm{G}$ using a solvent system which gave a better separation of FFA. Plates $(200 \mathrm{~mm}$ $\times 200 \mathrm{~mm}$ ) were initially developed for approximately $100 \mathrm{~mm}$ with diethyl etherglacial acetic acid ( $\left.5_{50}^{\circ} 2, \mathrm{v} / \mathrm{v}\right)$, dried, and then fully developed with diethyl etherammonia (prepared by shaking diethyl ether with to $\mathrm{ml}$ ammonia (sp. gr. 0.880 )). In this system, phospholipids remained at the origin, FFA were retained at the first solvent front, and all other lipids were found at the second solvent front. Lipid were visualized and transferred to vials for the measurement of radioactivity as 
described previously. Triglycerides in VLDL extracts were determined by the method of Carlson (1959). Serum FFA were estimated by the Trout, Estes \& Friedberg (1960) modification of the Dole procedure. ${ }^{14} \mathrm{CO}_{2}$ in respiratory gases was determined by the method of Mayes \& Felts (1966).

Other experimental details were as previously described by Topping \& Mayes (1972).

\section{Measurement of radioactivity}

Radioactivity was measured using a Packard 3003 liquid-scintillation spectrometer, and values were corrected for counting efficiency using an external standard and a computer programme (Felts \& Mayes, 1967). The scintillator solution used throughout was $12 \mathrm{ml}$ of a solution of $6 \mathrm{~g} \mathrm{2,5-diphenyloxazole} \mathrm{and} 0.03 \mathrm{~g} \mathrm{I,4}$-bis (4-methyl-5-phenyloxazol-2-yl)-benzene/l toluene, and $6 \mathrm{ml}$ ethanol (Industrial Methylated Spirit; James Burroughs Ltd, London).

\section{Statistical methods}

There were four experimental groups arranged as a $2 \times 2$ factorial experiment (Brownlee, 1949). These groups consisted of a control group (saline infusion), two groups where either glucose or fructose were infused alone and a fourth group in which they were infused together. The results were tested by analysis of variance, and $P<0.05$ was taken as the criterion of statistical significance. Values are given as mean values with their standard errors.

\section{RESULTS}

The statistical significance of the metabolic effects of fructose and glucose is summarized in Table $\mathrm{I}$. The weight of the liver at the end of perfusion (which averaged I $1.9 \mathrm{~g}$ for all groups) and the mean rate of bile flow ( $\mathrm{I} \cdot \mathrm{I} \mathrm{ml} / \mathrm{g}$ liver per $\mathrm{h}$ ) did not differ between any of the experimental groups.

\section{Carbohydrate metabolism}

Perfusate fructose. In livers where fructose was infused, concentrations in the perfusate remained stable at approximately $1.4 \mathrm{mmol}$ fructose $/ \mathrm{l}$ blood. It was found, in samples taken after 5 min of infusion, that these concentrations were established rapidly, and did not differ significantly between the two groups in which fructose was infused. Therefore the rate of uptake of fructose was unchanged by the infusion of glucose and fructose together. The mean proportional uptake of fructose by the liver (calculated by direct differences across the liver) was $39.5 \pm 2.4 \%$.

Perfusate glucose and liver glycogen. Concentrations of glucose in control perfusions reached a steady concentration of approximately $10.3 \mathrm{mmol} / 1$ blood (Fig. 1 ). In livers where glucose was infused alone, perfusate concentrations increased continuously throughout the experiment. However, when fructose was infused alone, the concentration of glucose was significantly lower than in the controls. The infusion of glucose and fructose together also resulted in a significant reduction in blood glucose, and the interaction between the two treatments was statistically significant $(P<0.05)$. 
Table I. Summary of the analysis of variance of a $2 \times 2$ factorial experiment on the effects of glucose and fructose infusion on the metabolism of perfused livers from fed rats

(Livers from fed rats were infused continuously with $\left[1-{ }^{14} \mathrm{C}\right]$ oleic acid for an experimental period of $90 \mathrm{~min}$ to maintain a concentration of approximately $0.8 \mathrm{mmol} \mathrm{FFA} / 1$ serum. There were four experimental groups, i.e. control (saline), +fructose, + glucose, and + glucose and fructose)

\section{Liver wt}

Bile production

Blood glucose (decrease)

Blood glucose (increase)

Glucose uptake (increase)

Fructose uptake (decrease)

Blood lactate (increase)

Liver glycogen (decrease)

FFA uptake

Oxidation to ${ }^{14} \mathrm{CO}_{2}$ (decrease)

Total ${ }^{14} \mathrm{C}$ esterification (increase)

VLDL-triglyceride production (increase)

${ }^{14} \mathrm{C}$ incorporation into VLDL-lipids (increase)

${ }^{14} \mathrm{C}$ incorporation into total liver lipids

(increase)

${ }^{14} \mathrm{C}$ incorporation into liver phospholipids (increase)

${ }^{14} \mathrm{C}$ incorporation into liver triglycerides

${ }^{14} \mathrm{C}$ incorporation into liver cholesteryl esters

${ }^{14} \mathrm{C}$ incorporation into liver mono- and

diglycerides and FFA

$\begin{array}{ccc}\text { Fructose } & \text { Glucose } & \begin{array}{c}\text { Fructose } \\ \times \text { glucose } \\ \text { interaction }\end{array} \\ \text { NS } & \text { NS } & \text { NS } \\ * & \text { NS } & \text { NS } \\ \text { NS } & \text { NS } & * \\ * * * & * * * & \text { NS } \\ * * * & \text { *** } & \text { N** } \\ * * * & \text { NS } & \text { NS } \\ \text { NS } & \text { NS } & \text { NS } \\ \text { NS } & \text { NS } & * \\ * * * & \text { NS } & \text { NS } \\ * * * & \text { NS } & * * * \\ * & \text { NS } & \text { NS } \\ * & \text { NS } & \text { NS } \\ * & \text { NS } & \text { NS } \\ * & \text { NS } & \text { NS } \\ * & \text { NS } & \text { NS } \\ * & \text { NS } & \text { NS } \\ \text { NS } & \text { NS } & \text { NS } \\ \text { NS } & \text { NS } & \text { NS }\end{array}$

FFA, free fatty acids; VLDL, very-low-density lipoproteins; NS, not significant.

Statistical significance of effect: $* P<0.05, * * * P<0.01$.

The concentration of liver glycogen at the end of the perfusions did not differ between control livers and those where fructose or glucose was infused alone, and averaged $14 \mathrm{mg} / \mathrm{g}$ wet weight (Fig. 2). However, in livers infused with fructose and glucose together, glycogen concentration was significantly higher than in the other groups $(27 \mathrm{mg} / \mathrm{g}$ wet weight).

Hepatic carbohydrate uptake and output. Perfusate glucose concentrations remained stable in control livers, indicating that hepatic glucose release equalled perfusate glucose utilization by erythrocyte glycolysis. From the rate of glucose utilization and lactate production of rat blood at $37^{\circ}$ (Topping \& Mayes, 1972) it was calculated that livers in the control group released $224 \mu \mathrm{mol}$ glucose/h (Table 2). It was assumed that the rate of utilization of glucose by perfusate erythrocytes did not differ between the experimental groups.

The absolute rate of uptake of fructose between 30 and $90 \mathrm{~min}$ by livers infused with fructose only was 5 or $\mu \mathrm{mol} / \mathrm{h}$. As perfusate glucose concentrations were significantly reduced in this group, hepatic glucose output was reduced as compared with the control group. When livers were infused with glucose alone, output from 


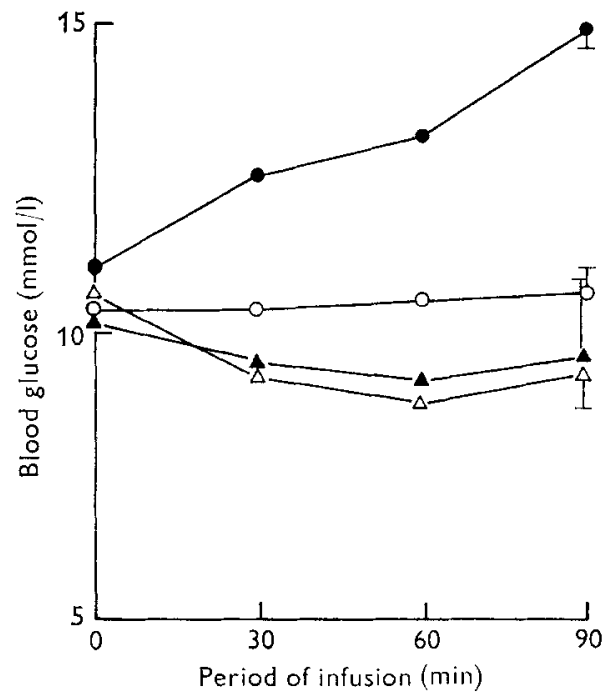

Fig. I

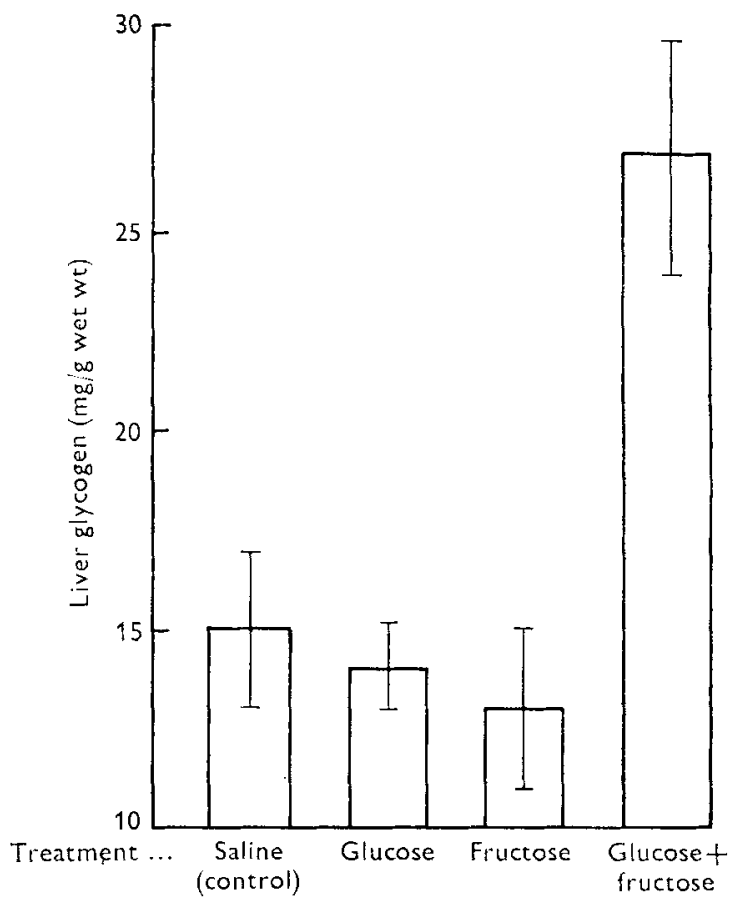

Fig. 2

Fig. I. Concentrations ( $\mathrm{mmol} / \mathrm{l})$ of blood glucose in perfused livers from fed rats. The livers were infused continuously with free fatty acid (FFA) $\left(\left[1-{ }^{14} \mathrm{C}\right]\right.$ oleic acid) to maintain a concentration of approximately $0.8 \mathrm{mmol} F F A / 1$ serum. There were four experimental groups which also received infusions of (values in parentheses indicate the no. of determinations/ treatment): saline (control) (4), (O); glucose alone (4), (O); fructose alone (4), ( $\triangle$ ); or fructose and glucose together $(3),(\mathbf{A})$. Points are mean values, with their standard errors represented by vertical bars. For details of infusion procedure, see pp. I $14-5$.

Fig. 2. Concentrations (mg/g wet weight) of liver glycogen in perfused livers from fed rats. The livers were infused continuously with free fatty acid (FFA) $\left(\left[\mathrm{I}^{14} \mathrm{C}\right]\right.$ oleic acid) to maintain a concentration of approximately $0.8 \mathrm{mmol} F F / 1$ serum. There were four experimental groups which also received infusions of (values in parentheses indicate the no. of determinations/treatment): saline (control) (4), glucose alone (4), fructose alone (3), or glucose and fructose together (4). Mean values, with their standard errors represented by vertical bars, are shown. For details of infusion procedure, see pp. I $14-5$.

the liver decreased to $12 \mathrm{I} \mu \mathrm{mol} / \mathrm{h}$, but when fructose and glucose were infused together there was a reversal in the flow of glucose such that there was a net uptake of glucose of $237 \mu \mathrm{mol} / \mathrm{h}$. The mean rate of fructose uptake by these livers was similar to that by livers infused with fructose alone, i.e. $487 \mu \mathrm{mol} / \mathrm{h}$. It should be noted that the increase in glucose uptake in the livers infused with fructose and glucose together was sufficient to account for the significantly increased concentration of liver glycogen found in this group.

Perfusate lactate. Mean concentrations of lactate at o min were in the range $4.8-6.2 \mathrm{mmol} / 1 \mathrm{blood}$. In the $90 \mathrm{~min}$ experimental period there was no significant change in lactate concentrations in either control or glucose-infused livers (Fig. 3) and thus the uptake of lactate by the perfused liver was in equilibrium with that 


\section{Table 2. Uptake and output $(\mu \mathrm{mol} / \mathrm{h})$ of fructose and glucose by perfused livers from fed rats}

(Livers from fed rats were infused continuously with $\left[\mathrm{I}^{14} \mathrm{C}\right]$ oleic acid for an experimental period of $90 \mathrm{~min}$ to maintain a concentration of approximately $0.8 \mathrm{mmol}$ free fatty acid/1 serum. Fructose was infused to maintain a concentration of $1.4 \mathrm{mmol} / \mathrm{l}$ blood and glucose was infused at a similar rate. Uptake was calculated from the net change in perfusate concentration and from the rate of infusion, allowing for erythrocyte glycolysis. Negative values indicate output. Mean values with their standard errors; no. of determinations in parentheses)

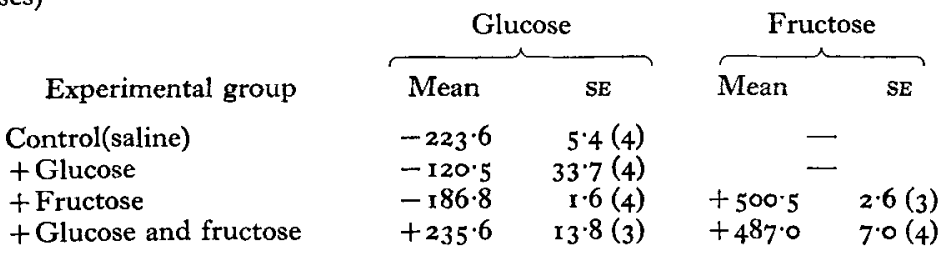

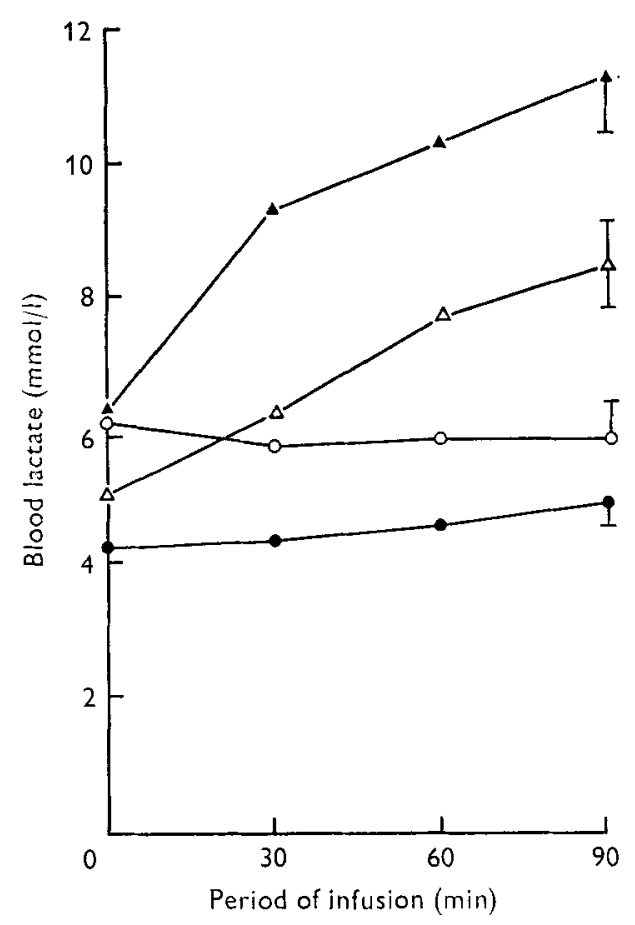

Fig. 3. Concentrations (mmol/l) of blood lactate in perfused livers from fed rats. The livers were infused continuously with free fatty acid (FFA) $\left(\left[\mathrm{r}-{ }^{14} \mathrm{C}\right]\right.$ oleic acid) to maintain a concentration of approximately $0.8 \mathrm{mmol} \mathrm{FFA} / 1$ serum. There were four experimental groups which also received infusions of: saline (control), (O); glucose alone, (O); fructose alone, $(\triangle)$; fructose and glucose together, $(\mathbf{A})$. Points are mean values, with their standard errors represented by vertical bars, for four experiments. For details of infusion procedure, see pp. II4-5. 
Table 3. Incorporation of $\left[\mathrm{I}^{14} \mathrm{C}\right]$ oleic acid into products of esterification and into ${ }^{14} \mathrm{CO}_{2}$ by perfused livers from fed rats

(Livers from fed rats were infused continuously with $\left[\mathrm{I}^{14} \mathrm{C}\right]$ oleic acid for an experimental period of $90 \mathrm{~min}$ to maintain a concentration of approximately $0.8 \mathrm{mmol}$ free fatty acid/1 serum. Fructose was infused to maintain a concentration of $144 \mathrm{mmol} / 1$ blood and glucose was infused at a similar rate. The products of esterification included liver and perfusate triglycerides, phospholipids and cholesteryl esters. Mean values with their standard errors; no. of determinations in parentheses)

\begin{tabular}{|c|c|c|c|c|}
\hline \multirow[b]{3}{*}{ Experimental group } & \multicolumn{4}{|c|}{ Incorporation (\%) into: } \\
\hline & \multicolumn{2}{|c|}{ Esterified products } & \multicolumn{2}{|c|}{${ }^{14} \mathrm{CO}_{2}$} \\
\hline & Mean & SE & Mean & SE \\
\hline Control (saline) & $56 \cdot 2$ & $I \cdot 6(4)$ & $5 \cdot 4$ & $0.6(4)$ \\
\hline + Glucose & $57 \cdot 0$ & $I \cdot 6(4)$ & $7 \cdot 3$ & $0.6(4)$ \\
\hline + Fructose & $70 \cdot 5$ & $x \cdot 9(4)$ & $3 \cdot 4$ & $0.0(3)$ \\
\hline+ Glucose and fructose & $75 \cdot 2$ & $37(4)$ & $\mathrm{I} \cdot 4$ & $0 \cdot 1(3)$ \\
\hline
\end{tabular}

derived from erythrocyte glycolysis. When fructose was infused alone or with glucose, lactate concentrations increased continuously throughout the period of perfusion, reaching concentrations which were higher than those at $0 \mathrm{~min}$ by $3-5 \mathrm{mmol} / \mathrm{l} \mathrm{blood}$. This effect of fructose was statistically highly significant $(P<0.01)$.

\section{Lipid metabolism}

Serum FFA. The infusion of $\left[\mathrm{I}^{14} \mathrm{C}\right]$ oleic acid increased the steady-state concentration of perfusate FFA from $0.2-0.4 \mathrm{mmol} / 1$ serum at $0 \mathrm{~min}$ to approximately $0.7-0.8 \mathrm{mmol} / 1$ serum. As in the instance of perfusate fructose, it was found that these increased levels were established within $5 \mathrm{~min}$ of the start of the infusion. Steady-state concentrations of perfusate FFA did not differ significantly between groups, indicating that neither the infusion of fructose nor that of glucose influenced hepatic uptake. This was confirmed by direct measurement of the concentration difference, hepatic portal venous - hepatic venous serum FFA. The mean fractional uptake calculated both from the rate of infusion and by direct measurement was found to be in the range $30-35 \%$.

Balance between the oxidation and esterification of serum ${ }^{14} C$-labelled $F F A$. An inverse relationship was found between the oxidation and the esterification of serum FFA by the liver (Mayes \& Felts, 1967), and this balance was again readily apparent in the present series of experiments. Livers in the control group oxidized $5 \%$ of infused $\left[\mathrm{I}^{14} \mathrm{C}\right]$ oleic acid to ${ }^{14} \mathrm{CO}_{2}$ and incorporated $56 \%$ into liver and perfusate lipids (Table 3). Glucose infusion did not alter the balance between oxidation and esterification. However, in fructose-infused livers the proportion of ${ }^{14} \mathrm{C}$-labelled FFA oxidized to ${ }^{14} \mathrm{CO}_{2}$ was significantly decreased to less than $4 \%$, while esterification was increased. When fructose and glucose were infused together, the oxidation of $\left[\mathrm{I}-{ }^{14} \mathrm{C}\right.$ ]oleic acid to ${ }^{14} \mathrm{CO}_{2}$ was decreased to $\mathrm{I} \%$ of the total ${ }^{14} \mathrm{C}$ infused, but, although net esterification increased, this was not statistically significant. This change in oxidation in livers infused with fructose and glucose together was due to a statistically significant $(P<0.0 \mathrm{I})$ interaction between the two hexoses. 


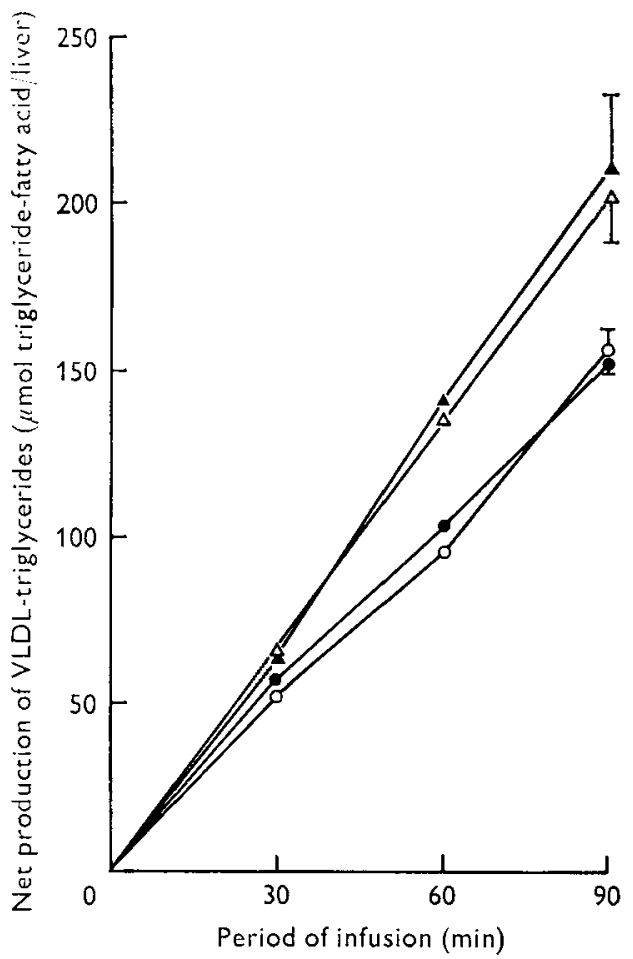

Fig. 4. Net production ( $\mu \mathrm{mol}$ triglyceride-fatty acid/liver) of triglycerides in very-low-density lipoproteins (VLDL) in perfused livers from fed rats. The livers were infused continuously with free fatty acid (FFA) ([I- $\left.{ }^{14} \mathrm{C}\right]$ oleic acid) to maintain a concentration of approximately $0.8 \mathrm{mmol} F F A / 1$ serum. There were four experimental groups which also received infusions of (values in parentheses indicate no. of determinations/treatment): saline (control) $(4),(O)$; glucose alone (4), (O); fructose alone $(4),(\Delta)$; fructose and glucose together $(3),(\Delta)$. Points are mean values, with their standard errors represented by vertical bars. For details of infusion procedure, see $\mathrm{pp}$. 1 14-5.

$V L D L$-triglyceride secretion. The relationship for VLDL-triglyceride secretion by the perfused liver $v$. period of infusion was linear in all groups (Fig. 4). Control and glucose-infused livers released similar amounts of VLDL-triglyceride into the perfusate during the $90 \mathrm{~min}$ experimental period, i.e. ${ }_{55}$ and ${ }_{5} 52 \mu \mathrm{mol}$ triglyceridefatty acid/liver respectively. In the two groups where fructose was infused there was a significant increase in triglyceride release. Livers in the fructose group released $202 \mu \mathrm{mol}$ triglyceride-fatty acid $/ 90 \mathrm{~min}$. This value did not differ significantly from that for the total secretion by livers infused with both fructose and glucose, i.e. $210 \mu \mathrm{mol}$ triglyceride-fatty acid $/ 90 \mathrm{~min}$.

Incorporation of $\left[\mathrm{I}^{14} \mathrm{C} C\right]$ oleic acid into perfusate and liver lipids. Control livers and those infused with glucose incorporated approximately $17 \%$ of total infused ${ }^{14} \mathrm{C}$ labelled FFA into VLDL-lipids (Table 4), but the infusion of fructose, both alone and with glucose, significantly increased incorporation to 22.0 and $24.2 \%$ of the $\left[{ }^{1-14} \mathrm{C}\right]$ oleic acid infused respectively. There was no statistically significant interaction between fructose and glucose. Of the ${ }^{14} \mathrm{C}$-labelled FFA incorporated into 
Table 4. Incorporation (\%) of $\left[{ }^{1}-{ }^{14} C\right]$ oleic acid into very-low-density lipoproteins (VLDL) and liver lipids by perfused livers from fed rats

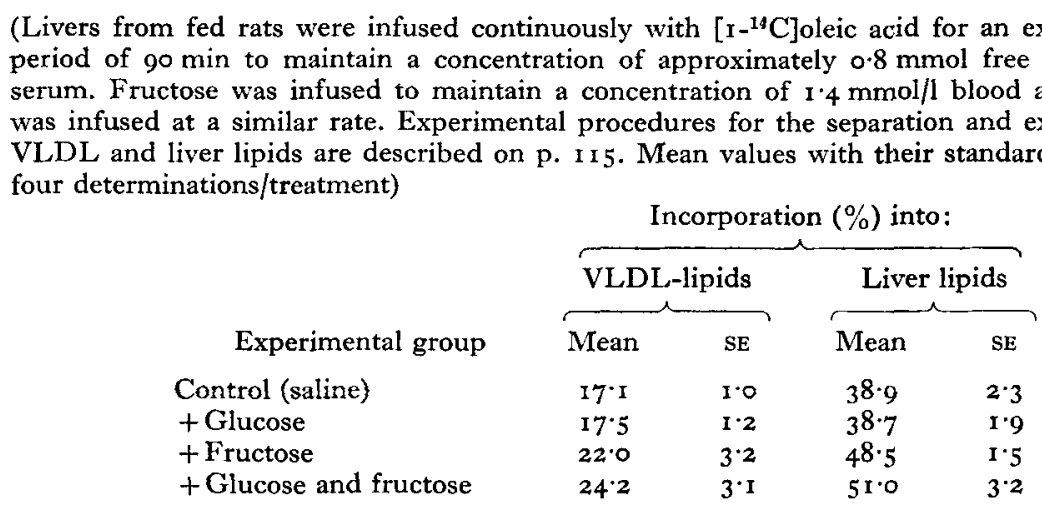

perfusate VLDL-lipids, the main proportion $(96 \%)$ was recovered in triglycerides, and only small amounts of radioactivity were found in phospholipids, FFA and cholesteryl esters. This pattern of incorporation between the various classes of lipids was unaffected by any of the experimental treatments.

Approximately $36-40 \%$ of the total $\left[{ }^{1-14} \mathrm{C}\right]$ oleic acid infused was recovered in liver lipids at the end of the perfusion in both control and glucose-infused groups (Table 4). This incorporation was significantly $(P<0.05)$ increased to nearly $50 \%$ of infused ${ }^{14} \mathrm{C}$-labelled FFA in both groups where fructose was infused. Of the total radioactivity recovered in liver lipids, approximately $30 \%$ was found in phospholipids, $60 \%$ in triglycerides and the main proportion of the remainder in mono- and diglycerides. Only trace quantities of ${ }^{14} \mathrm{C}$ were found in liver FFA and cholesteryl esters. The pattern of distribution was unchanged by either glucose or fructose infusion.

Analysis of ${ }^{14} \mathrm{C}$ in lipoprotein-lipids (density $<\mathrm{I} \cdot 006 \times 10^{3} \mathrm{~kg} / \mathrm{m}^{3}$ ) indicated that most of the radioactivity $(95 \%)$ was found in the fatty acids, representing the infused $\left[\mathrm{I}^{-14} \mathrm{C}\right]$ oleic acid, only small quantities of tracer being found in other lipid classes.

\section{DISCUSSION}

These experiments were done to study the separate and combined effects of fructose and glucose on the secretion of VLDL-triglycerides and the related metabolism of the perfused liver. The studies were designed particularly to determine whether the hypertriglyceridaemic effect of feeding sucrose could be related to a non-specific effect of flooding the liver with monosaccharides, or to specific metabolic differences between the fructose and glucose molecules. Thus fructose and glucose were compared by infusing the two sugars at equimolar rates and in physiological quantities into livers perfused with homologous whole blood, at rates of flow similar to those encountered in vivo.

The results of previous studies (Topping \& Mayes, 197I) indicated that the 
maximum concentrations of fructose found in the hepatic portal vein of rats absorbing a large meal of fructose were in the range $\mathbf{I} \cdot \mathbf{I}-2 \cdot \mathbf{2} \mathrm{mmol} / \mathrm{l}$ blood. These concentrations are very much lower than those used by many workers for studies in vitro, and those at which hepatocellular damage has been found to occur in vivo (Phillips, Hetenyi \& Adachi, 1970). There was no evidence of any impairment of liver function in the present experiments.

\section{Carbohydrate metabolism}

When fructose was infused alone, a steady-state was rapidly reached in the perfusate with concentrations remaining in the region of $\mathrm{I} \cdot 4 \mathrm{mmol} / \mathrm{l}$ blood. The infusion of glucose alone resulted in a continuous increase in its blood concentration due to incomplete removal from the perfusate by the liver. These findings confirm earlier work with liver slices on the differences between glucose and fructose done at much higher concentrations of substrate (Chernick, Chaikoff \& Abraham, I95I; Renold, Hastings \& Nesbett, I954), and is a reflexion of the much lower value for the Michaelis constant of fructokinase $(E C$ 2.7.1.4) for fructose when compared with that of glucokinase $(E C$ 2.7.1.2) for glucose (Sillero, Sillero \& Sols, 1969).

The infusion of fructose alone resulted in a significant reduction in blood glucose concentration. The infusion of fructose and glucose together resulted in a large increase in hepatic glucose utilization, with no change in the utilization of fructose. Reductions in glucose concentrations have been reported in the hepatic venous blood of rats absorbing a fructose meal (Topping \& Mayes, 1971). Seglen (1974) has also reported a synergistic effect on glycogenesis in liver cells at high and unphysiological concentrations of the two hexoses. More than one explanation may be offered for these findings. The concentration of glucose in the perfusate is the result of the balance between hepatic uptake and output, the released glucose being derived from glycogenolysis or gluconeogenesis. In fasting, the latter process predominates, while in the fully-fed state glycogen would also be available as an important source. The state of the perfused livers in the present experiments is probably between these two nutritional extremes, with glucose derived from both glycogenolysis and gluconeogenesis. Fructose is known to cause increases in hepatic glucose-6-phosphate concentrations (Walli, Birkmann \& Schimassek, 1976), which may in turn activate glycogen synthetase (UDPglucose:glycogen $\alpha$-4-glucosyltransferase; $E C$ 2.4.I.II) and inhibit phosphorylase ( $E C$ 2.4.I.I) activity (Hers, Stalmans, de Wulf, Laloux \& Hue, 1974), thus allowing a net reduction in glucose output in livers infused with fructose alone, or a stimulation of glucose uptake when fructose and glucose are infused together. In effect, fructose may 'open the door' for hepatic glucose uptake and glycogen synthesis. However, the enhanced uptake of glucose in livers infused with both monosaccharides did not lead to greatly increased esterification of FFA or extra production of VLDL-triglyceride. This would appear to indicate that most of the enhanced glucose uptake was directed towards glycogen synthesis rather than towards glycolysis. In addition, an inhibition of gluconeogenesis leading to a reduction in glucose output may be due to an increased concentration of fructose-1,6-diphosphate. This would result from the fructose infusion and lead 
to inhibition of D-fructose-r,6-diphosphate I-phosphohydrolase (EC 3.I.3.II) (Underwood \& Newsholme, 1965), a key enzyme in the pathway of gluconeogenesis. This mechanism was probably operating when fructose was infused both alone and with glucose, since lactate concentrations (and therefore probably fructose-r,6-diphosphate concentrations) were increased to the same extent under both conditions.

\section{Lipid metabolism}

The different effects of fructose and glucose would appear to be due largely to the differences in the metabolism of the two hexoses by the liver. The hepatic metabolism of fructose is mainly by the pathway described by Hers et al. (1974) which is relatively independent of the controls exerted on the utilization of glucose by the liver (Sillero et al. 1969). Thus, the addition of fructose both in vivo (Heinz \& Junghänel, I969) and in vitro (Woods, Eggleston \& Krebs, I970) is known to increase the concentrations of hepatic intermediates, including $S n$-glycerol-3-phosphate, pyruvate and lactate. The increase found in perfusate lactate was probably a reflexion of increased hepatocellular concentrations due to the uptake of fructose. Availability of $\mathrm{Sn}$-glycerol-3-phosphate may be important in the regulation of hepatic fatty acid esterification (Fritz, 196r; Tzur, Tal \& Shapiro, 1964) and it can be suggested that as the oxidation and esterification of FFA are reciprocally related, the decreased oxidation of ${ }^{14} \mathrm{C}$-labelled FFA found in the fructose-infused groups was due to an increased concentration of this metabolite. In support of this Pereira \& Jangaard (I97I) have reported a significant incorporation of $\left[{ }^{14} \mathrm{C}\right]$ fructose into liver glycerideglycerol. However, it must be recognized that the status of $S n$-glycerol-3-phosphate as a regulator of esterification is uncertain. Denton \& Randle (1967) have found that, in adipose tissue, changes in the concentrations and flux of this intermediate did not reflect corresponding changes induced in the esterification of fatty acids. It is also possible that fructose may have spared fatty acid oxidation by supplying acetyl-CoA via pyruvate for oxidation. In adipose tissue both fructose and glucose increase the activity of pyruvate dehydrogenase $(E C$ I.2.4.1), with fructose having the greater effect (Wieland, Siess, Weiss, Löffler, Patzelt, Portenhauser, Hartmann \& Schirmann, I973), and in liver, in addition to increasing $S n$-glycerol-3phosphate, fructose administration has been found to increase hepatic concentrations of pyruvate, which would be likely to activate pyruvate dehydrogenase and so increase oxidation of carbohydrate via the tricarboxylic acid cycle (Bremer, Bjerre, Christophersen, Daae, Solberg \& Aas, 1974).

Glucose infused alone had no effect on the balance between the oxidation and esterification of FFA by the perfused liver. However, when fructose and glucose were infused together there was a significant decrease in fatty acid oxidation compared with that found with fructose alone, and a marginal increase in both esterification and the secretion of ${ }^{14} \mathrm{C}$-labelled VLDL. This is likely to be due to the enhancement of glucose uptake by fructose in this experimental group.

Previously (Topping \& Mayes, I972) it was argued that factors enhancing hepatic triglyceride secretion, such as fructose, did so by increasing the net synthesis of triglycerides in a small pool of high turnover which was the immediate precursor 
of VLDL-triglycerides. However, as fructose did not increase the incorporation of serum ${ }^{14} \mathrm{C}$-labelled FFA into VLDL, the existence of other precursor pools was suggested. The present results indicate quite unequivocally that fructose enhances the incorporation of ${ }^{14} \mathrm{C}$-labelled FFA into VLDL, thus removing the necessity for extra precursor pools in the model. This present finding is probably due to the use of an improved perfusion technique. The present studies were done under the same conditions as those used by P. A. Mayes \& J. M. Felts (unpublished results); the rate of perfusion was increased to the physiological level, giving improved hepatic $\mathrm{O}_{2}$ consumption, which resulted in higher rates of triglyceride secretion and more normal perfusate glucose concentrations.

\section{Conclusions}

The present results indicate clearly that large differences exist in the hepatic metabolism of fructose and glucose, and that these differences are of nutritional relevance in the development of hypertriglyceridaemia. The infusion of the two monosaccharides together resulted in a greatly enhanced uptake of glucose by the liver, which may have significance on the long-term adaptive effects of diets rich in sucrose.

The authors thank Mr R. S. Gardner and Mr A. Mangalgi for expert assistance; and the Medical Research Council for financial support.

\section{REFERENCES}

Bremer, J., Bjerre, K. S., Christophersen, B. O., Daae, L. N. W., Solberg, H. E. \& Aas, M. (1974). In Regulation of Hepatic Metabolism, p. I 59 [F. Lundquist and N. Tygstrup, editors]. Copenhagen: Einar Munksgaard.

Brownlee, K. A. (1949). Industrial Experimentation, 4th ed. London: H.M. Stationery Office.

Bruce, H. M. \& Parkes, A. S. (1949). J. Hyg., Camb. 47, 202.

Carlson, L. A. (1959). Acta Soc. Med. upsal. 64, 208.

Chernick, S. S., Chaikoff, I. L. \& Abraham, S. (1951). Y. biol. Chem. 193, 793.

Denton, R. M. \& Randle, P. J. (r967). Biochem. $\mathcal{~}$. ro4, 423.

Felts, J. M. \& Mayes, P. A. (x967). Biochem. f. xo5, 735.

Fritz, I. B. (196I). Physiol. Rev. 41, 52.

Good, C. A., Kramer, H. \& Somogyi, M. (1933). F. biol. Chem. 1oo, 485.

Havel, R. J., Felts, J. M. \& Van Duyne, C. M. (1962). F. Lipid Res. 3, 297.

Heinz, F. \& Junghänel, J. (1969). Hoppe-Seyler's Z. physiol. Chem. 350, 859.

Hers, H. G., Stalmans, W., de Wulf, H., Laloux, M. \& Hue, L. (1974). In Regulation of Hepatic Metabolism, p. 237 [F. Lundquist and N. Tygstrup, editors]. Copenhagen: Einar Munksgaard.

Hohorst, H. J. (1965). In Methods of Enzymatic Analysis, p. 266 [H. U. Bergmeyer, editor]. London and New York: Academic Press.

Krebs, H. A. \& Henseleit, K. (1932). Hoppe-Seyler's Z. physiol. Chem. 210, 33.

Long, E. C. (1957). Studies in foetal carbohydrate metabolism. PhD Thesis, University of London.

Macdonald, I. (1965). Clin. Sci. 29, 193.

Mayes, P. A. \& Felts, J. M. (1966). Proc. Eur. Soc. Stud. Drug Toxic. 7, 16.

Mayes, P. A. \& Felts, J. M. (1967). Nature, Lond. 215, 716.

Mayes, P. A. \& Topping, D. L. (1974). Biochem. F. I40, II I.

Naismith, D. J. (197 I). Proc. Nutr. Soc. 30, 259.

Pereira, J. N. \& Jangaard, N. O. (197I). Metabolism 20, 392.

Phillips, M. J., Hetenyi, A. \& Adachi, F. (1970). Lab. Invest. 22, 370.

Renold, A. E., Hastings, A. B. \& Nesbett, F. B. (1954). F. biol. Chem. 209, 687.

Roe, J. H. (1934). F. biol. Chem. ro7, I5.

Seglen, P. O. (1974). Biochim. biophys. Acta 338, 317. 
Sillero, M. A. G., Sillero, A. \& Sols, A. (1969). Eur. F. Biochem. 10, 345.

Stein, Y. \& Shapiro, B. (1959). Am. Y. Physiol. r96, 1238.

Topping, D. L. \& Mayes, P. A. (197I). Nutr. Metab. 13, 33 r.

Topping, D. L. \& Mayes, P. A. (1972). Biochem. F. 126, 295.

Topping, D. L. \& Mayes, P. A. (1973). Biochem. Soc. Trans. r, 433.

Trout, D. L., Estes, E. H. \& Friedberg, S. J. (1960). F. Lipid Res. 1, 199.

Tzur, R., Tal, E. \& Shapiro, B. (1964). Biochim. biophys. Acta 84, I8.

Underwood, A. H. \& Newsholme, E. A. (1965). Biochem. F. 95, 767.

Walli, A. K., Birkmann, L. \& Schimassek, H. (1976). Biochem. Soc. Trans. (In the Press.)

Wieland, O. H., Siess, E. A., Weiss, L., Löffler, A., Patzelt, C., Portenhauser, R., Hartmann, V. \& Schirmann, S. (1973). Symp. Soc. exp. Biol. 23, 371 .

Windmueller, H. G. \& Spaeth, A. E. (1967). Archs Biochem. Biophys. 122, 362.

Woods, H. F., Eggleston, L. V. \& Krebs, H. A. (1970). Biochem. F. II9, 501. 